\title{
Pemahaman Konsep Siswa pada Aktivitas Kerja Kelompok Berbasis CTL REACT
}

\author{
${ }^{1}$ Imro'atul Mubarokah, ${ }^{2}$ Cholis Sa'dijah, ${ }^{3}$ Hery Susanto \\ Jurusan Matematika FMIPA Universitas Negeri Malang \\ Jl. Semarang No.5, Sumbersari, Kec. Lowokwaru, Kota Malang, Jawa Timur, \\ Indonesia
}

Email: 1imroatul.mbarokah.1903117@students.um.ac.id, ${ }^{2}$ cholis.sadijah.fmipa@um.ac.id, ${ }^{3}$ hery.susanto.fmipa@um.ac.id

\section{Tersedia Online di \\ http://www.jurnal.unublitar.ac.id/ index.php/briliant}

\begin{tabular}{l}
\hline Sejarah Artikel \\
\hline Diterima pada Februari 2021 \\
Disetuji pada Mei 2021 \\
Dipublikasikan pada Mei 2021 \\
Hal. 376-388 \\
\hline \\
\hline Kata Kunci: \\
Pemahaman Konsep Siswa; \\
Aktivitas Kerja Kelompok; CTL \\
REACT
\end{tabular}

\section{DOI:}

http://dx.doi.org/10.28926/brilian t.v3i4.635

\begin{abstract}
Abstrak: Pemahaman konsep matematika siswa MAN 1 Tuban masih rendah. Hal ini dibuktikan dengan hasil tes matematika yang rata-ratanya masih belum bisa mencapai ketuntasan belajar secara klasikal. Salah satu penyebabnya adalah kesalahan guru yang hanya fokus pada operasional siswa. Untuk itu, penelitian ini bertujuan untuk menganalisis pemahaman konsep siswa yaitu pada materi matriks berdasarkan komponen pemahaman konsep siswa dengan indikator yang sudah ditetapkan oleh peneliti. Penelitian ini merupakan penelitian deskriptif kualitatif. Metode yang digunakan dalam penelitian ini adalah tanya jawab, diskusi dan penugasan untuk mengetahui pemahaman konsep siswa pada Lembar Kerja Kelompok (LKK) berbasis CTL REACT. Subyek penelitian ini adalah siswa MAN 1 Tuban kelas XI-IPS 5 semester 1 pada Tahun Pelajaran 2020/2021 dengan jumlah 11 siswa dan dibentuk menjadi 3 kelompok secara hiterogen. Adapun Instrumen yang digunakan dalam penelitian ini adalah lembar kerja berupa aktivitas kerja kelompok berbasis CTL REACT yang selanjutnya disebut Lembar Kerja Kelompok (LKK) berbasis CTL REACT. Setelah diperoleh hasil persentase
\end{abstract} pemahaman konsep siswa dan level pencapaian setiap indikator pada setiap pertemuan, maka dapat disimpulkan bahwa dalam menyatakan ulang konsep 75\% siswa mencapai level 3 dan $25 \%$ siswa mencapai level 2. Mengklasifikasikan objek menurut sifat tertentu 32\% siswa mencapai level 3 dan $68 \%$ siswa mencapai level 2. Memberikan contoh dan bukan contoh konsep 57\% siswa mencapai level 3 dan $43 \%$ siswa mencapai level 2. Menyajikan konsep dalam representasi matematis $93 \%$ siswa mencapai level 3 dan 7\% siswa mencapai level 2 dan dalam mengaplikasikan konsep pada pemecahan masalah dalam proses pembelajaran matematika $68 \%$ siswa mencapai level 3 dan $32 \%$ siswa mencapai level 2. Dari asil analisis data tersebut dapat disimpulkan bahwa pemahaman konsep siswa berada pada level 2 dan 3. Ini artinya, siswa paham konsep matematika tentang materi matriks meskipun ada beberapa yang tidak lengkap atau kurang tepat.

\section{PENDAHULUAN}

Matematika merupakan salah satu ilmu yang memiliki peran penting dalam pemikiran abad ke-21 (Dewanti, dkk., 2020). Selanjutnya menurut Suraji \& Maimunah (2018), jika dilihat dari sudut pengklasifikasian bidang ilmu pengetahuan, matematika termasuk ilmu eksakta yang lebih banyak memerlukan pemahaman bukan hanya sekedar hafalan. Dalam proses pembelajaran matematika, agar siswa dapat mengaplikasikan konsep secara tepat dan efisien siswa harus 
memiliki kemampuan pemahaman konsep yang baik (Mawaddah \& Maryanti, 2016). Karena dengan memahami suatu konsep, memungkinkan siswa untuk menggunakan suatu ide dan menyesuaikan beberapa ide matematika yang dikuasai ke situasi-situasi baru sehingga belajar akan semakin bermakna (National Council Of Teachers Of Mathematics, 2000).

Pemahaman konsep merupakan salah satu keterampilan penting yang harus dimiliki siswa dalam mempelajari matematika. Hubungan antara konsep satu dengan konsep yang lain akan membentuk sebuah pengetahuan baru yang tidak dapat dipisahkan (Susiswo, 2014). Selanjutnya menurut (Aledya, 2019), siswa akan mempunyai dasar dalam mempelajari konsep matematika yang lebih tinggi apabila siswa memahami konsep sebelumnya dengan baik. Selain itu, Rikmasari (2018) menyatakan bahwa pemahaman konsep merupakan kemampuan siswa dalam menerima dan menyerap materi dimana siswa diharapkan mampu mengungkapkan kembali, mampu memberikan contoh, mampu memahami materi, mampu mengaitkan materi dengan kehidupan saat ini, dan mampu memberikan kesimpulan terhadap materi.

Siswa dikatakan mampu memahami konsep dengan baik jika siswa tersebut mampu mendefinisikan konsep dengan kalimatnya sendiri, mengklasifikasikan objek berdasarkan persyaratan tertentu, mengidentifikasi sifatsifat konsep, menerapkan konsep, memberi contoh atau bukan contoh dari suatu konsep, menyajikan konsep dalam berbagai representasi, mengaitkan konsep yang satu dengan konsep lainnya, dan mengembangkan syarat perlu dan syarat cukup suatu konsep (Mulyono \& Hapizah, 2018; Rikmasari, 2018; Aledya, 2019). Selain itu, menurut Garegae (2007) pemahaman juga dapat dijadikan sebagai indikator bagi guru untuk mengetahui ketercapaian tujuan pembelajaran. Maka dapat disimpulkan bahwa salah satu keahlian penting yang harus menjadi tujuan pembelajaran matematika di sekolah adalah pemahaman konsep.

Menurut Eggen, P., \& Kauchak (2012) pengetahuan dan pemahaman konsep siswa bisa diukur melalui empat cara, yaitu kita dapat meminta mereka untuk: (1) mendefinisikan konsep; (2) mengidentifikasi karakteristik-karakeristik konsep; (3) menghubungkan konsep dengan konsep-konsep lain; (4) mengidentifikasi atau memberikan contoh dari konsep yang belum pernah dijumpai sebelumnya. Selanjutnya pemahaman konsep yang digunakan peneliti sebagai acuan dalam penelitian ini adalah pemikiran siswa dalam memahami konsep matematika sehingga siswa dapat menyatakan ulang konsep, mengklasifikasikan objek menurut sifat tertentu, memberikan contoh dan bukan contoh konsep, menyajikan konsep dalam representasi matematis, dan mengaplikasikan konsep pada pemecahan masalah dalam proses pembelajaran matematika (Mawaddah, S., \& Maryanti, 2016).

Akan tetapi menurut Bingolbali, dkk. (2011), sebagian besar siswa pada umumnya masih mengalami kesulitan dalam hal memahami konsep, mengabstraksi konsep, dan mengaitkan matematika dengan kehidupan sehari-hari. Adapun salah satu kendala yang dialami siswa dalam memahami konsep diantaranya juga disebabkan oleh kesalahan guru yang hanya fokus pada operasional siswa tanpa mendidik mereka dari perspektif konseptual (Karadeniz, dkk., 2017). Sedangkan berdasarkan pengalaman peneliti selama mengajar di MAN 1 Tuban, dapat 
disimpulkan bahwa pemahaman konsep matematika siswa masih rendah. Hal ini dibuktikan dengan hasil tes matematika yang rata-ratanya masih belum bisa mencapai ketuntasan belajar secara klasikal.

Selain itu, guru harus memiliki kreativitas dalam menyusun bahan ajar yang inovatif, variatif, menarik, kontekstual dan sesuai dengan tingkat kebutuhan siswa agar siswa dapat memahami suatu konsep dengan baik (Prastowo, 2012). Selanjutnya proses pembelajaran matematika di kelas akan berhasil dan dapat dicapai secara optimal salah satunya melalui penggunaan bahan ajar berupa LKS yang sesuai dengan karakteristik atau kebutuhan siswa sehingga mampu mengatasi kesulitan-kesulitan siswa (Purwasi, L. A., \& Fitriyana, 2019). Sedangkan menurut (Hamdani, 2011), salah satu jenis alat bantu pembelajaran adalah Lembar Kerja Siswa (LKS). Jika guru sebagai pendidik hanya terpaku pada bahan-bahan ajar konvensional maka mutu pembelajaran akan menjadi rendah (Prastowo, 2012).

Berdasarkan hasil wawancara peneliti dengan salah satu guru Matematika di MAN 1 Tuban menyatakan bahwa pada umumnya guru masih menggunakan bahan ajar konvensional atau LKS yang didapat melalui distributor yang datang ke sekolah-sekolah. Sedangkan menurut pengamatan peneliti, LKS tersebut biasanya hanya sebatas menyajikan materi dalam bentuk final sudah jadi, disertai dengan contoh soal dan banyak latihan soal yang mengakibatkan siswa hanya menghafal konsep. Menurut (Prastowo, 2012), salah satu penyebab siswa kurang maksimal dalam memahami sebuah konsep pembelajaran adalah penggunaan LKS yang belum mengoptimalkan keikutsertaan siswa. Hal itu membuat siswa merasa bosan dalam mengikuti proses pembelajaran, sehingga menjadikan proses pembelajaran tidak efektif dan tidak efisien (Fitriyana \& Purwasi, 2020).

Adapun dalam penelitian ini, lembar kerja yang digunakan berupa aktivitas kerja kelompok berbasis CTL REACT yang selanjutnya disebut Lembar Kerja Kelompok (LKK) berbasis CTL REACT. Kemudian pada fase applying proses pembelajaran CTL REACT, guru memberikan LKK dengan bentuk soal kontekstual yang harus dikerjakan dengan kelompoknya masing-masing. Makna dari kontekstual itu sendiri adalah sesuatu yang berkaitan antara materi dengan lingkungan atau dunia sekitarnya yang pernah dilihat atau yang pernah dirasakan (Puspita \& Purwo, 2019).

Menurut Pangemanan (2020), pendekatan Contextual Teaching and Learning (CTL) merupakan suatu implementasi yang dapat membantu siswa untuk memahami konsep dan terampil dalam menyelesaikan masalah. Pembelajaran kontekstual yang disusun untuk mendorong siswa terlibat aktif di dalam kelas salah satunya adalah pengajaran berdasarkan strategi REACT. Hal ini sejalan dengan Nawas (2018) yang menyatakan bahwa pendekatan Contextual Teaching and Learning (CTL) melalui strategi REACT (Relating, Experiencing, Applying, Cooperating dan Transfer) dapat membantu siswa untuk berpikir kritis dan memahami materi yang mereka pelajari kemudian menghubungkan mata pelajaran dengan konteks kehidupan mereka.

Sedangkan proses pelaksanaan pembelajaran CTL REACT adalah sebuah siklus kegiatan, artinya proses tersebut tidak pernah terputus. Adapun siklus kegiatannya seperti yang disajikan pada Gambar 1 berikut (Cord, 1999). 


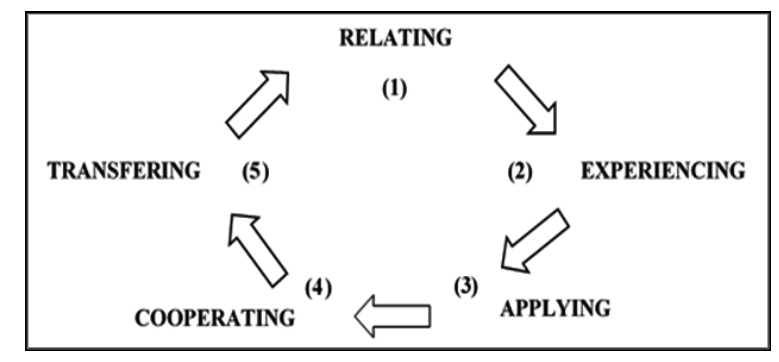

Gambar 1. Siklus Kegiatan Pelaksanaan Pembelajaran CTL REACT

Menurut Sari \& Darhim (2020), pembelajaran dengan strategi REACT akan memperkaya pemahaman konsep siswa dengan aktivitas langsung. Selain itu juga akan memberikan banyak pengalaman belajar bagi siswa, karena siswa tidak hanya menguasai isi mata pelajaran tetapi mereka juga belajar bagaimana belajar.

Pada kurikulum 2013 revisi 2017, materi matematika wajib kelas XI SMA/MA yang harus dipelajari dan dipahami siswa salah satunya adalah matriks. Menurut Aminullah (2018), matriks merupakan salah satu bentuk representasi matematika berupa susunan bilangan-bilangan yang dibentuk dalam baris dan kolom yang membentuk suatu persegi atau persegi panjang dimana sistem penulisannya dibatasi oleh kurung siku atau kurung biasa. Materi Matriks ini merupakan salah satu materi yang berkaitan erat dengan kehidupan siswa, yaitu digunakan untuk menyelesaikan masalah sistem persamaan linear dan analisis dalam bidang ekonomi, statistika, pendidikan, manajemen, kimia dan bidang teknologi lainnya (Zahara, dkk., 2020). Dengan mengetahui manfaat mempelajari materi matriks tersebut, maka dalam pembelajaran matematika guru perlu memberikan pemahaman konsep matriks kepada siswa dengan menggunakan LKK berbasis CTL REACT.

Berdasarkan latar belakang permasalahan dan pengalaman peneliti selama mengajar yang diuraikan di atas, maka penulis perlu melakukan penelitian lebih lanjut tentang "Analisis Pemahaman Konsep Siswa pada Aktivitas Kerja Kelompok Berbasis CTL REACT'. Adapun tujuan dalam penelitian ini adalah untuk menganalisis pemahaman konsep siswa pada materi matriks sesuai dengan indikator pemahaman konsep siswa yang sudah ditetapkan oleh peneliti.

\section{METODE}

Penelitian ini adalah penelitian deskriptif kualitatif. Metode yang digunakan adalah tanya jawab, diskusi dan penugasan. Selanjutnya tujuan dalam penelitian ini adalah menganalisis pemahaman konsep siswa pada materi matriks berdasarkan komponen pemahaman konsep dengan indikator yang sudah ditetapkan oleh peneliti. Subyek yang digunakan dalam penelitian ini adalah siswa MAN 1 Tuban kelas XI-IPS 5 semester 1 Tahun Pelajaran 2020/2021 yang berjumlah 11 siswa dan dibentuk menjadi 3 kelompok secara hiterogen.

Instrumen dalam penelitian ini adalah lembar kerja berupa aktivitas kerja kelompok berbasis CTL REACT yang selanjutnya disebut Lembar Kerja Kelompok (LKK) berbasis CTL REACT. Dalam penelitian ini, pemahaman konsep siswa dapat 
dilihat pada hasil Lembar Kerja Kelompok (LKK) yang dikerjakan bersama kelompoknya masing-masing. Sebelum LKK diberikan kepada siswa, peneliti melakukan validasi terlebih dahulu untuk mengetahui relevan atau tidaknya LKK tersebut. Validasi instrumen dalam penelitian ini dilakukan oleh satu dosen matematika dan dua orang guru matematika.

Menurut Khansa, dkk. (2018), kriteria dan level pemahaman konsep tentang matriks pada setiap indikator yang digunakan dalam penelitian ini adalah sebagai berikut: 1) Level 0, jika kelompok tidak paham konsep matematika. 2) Level 1, jika kelompok paham konsep matematika tetapi salah. 3) Level 2, jika kelompok paham konsep matematika tetapi tidak lengkap/kurang tepat. 4) Level 3, jika kelompok paham konsep matematika dengan benar dan tepat.

Indikator kinerja pada penelitian ini adalah setidaknya $70 \%$ siswa mencapai level 2 atau lebih pada setiap indikator pemahaman konsep tentang materi matriks dengan asumsi level pemahaman siswa sama dengan level pemahaman pada kelompok. Selanjutnya untuk menganalisis pemahaman konsep siswa, digunakan indikator pemahaman konsep materi matriks berdasarkan Tabel 1 berikut:

Tabel 1. Indikator Pemahaman Konsep Materi Matriks

\begin{tabular}{clll}
\hline No. & \multicolumn{1}{c}{ Indikator } & \multicolumn{3}{c}{ Bentuk Kegiatan yang Dilakukan Siswa } \\
\hline 1 & Menyatakan ulang konsep & $\begin{array}{l}\text { Menyatakan soal kontekstual dalam bentuk } \\
\text { matriks }\end{array}$ \\
\hline 2 & $\begin{array}{l}\text { Mengklasifikasikan objek } \\
\text { menurut sifat tertentu }\end{array}$ & $\begin{array}{l}\text { Menentukan jenis matriks yang matriksnya } \\
\text { dibuat sendiri oleh siswa dari masalah } \\
\text { kontekstual }\end{array}$ \\
\hline 3 & $\begin{array}{l}\text { Memberikan contoh dan } \\
\text { bukan contoh konsep }\end{array}$ & $\begin{array}{l}\text { Memberikan contoh elemen matriks, matriks dan } \\
\text { transpos matriks yang matriksnya dibuat sendiri } \\
\text { oleh siswa dari masalah kontekstual }\end{array}$ \\
\hline 4 & $\begin{array}{l}\text { Menyajikan konsep dalam } \\
\text { representasi matematis }\end{array}$ & $\begin{array}{l}\text { Merepresentasikan definisi dan } \\
\text { matriks }\end{array}$ & sifat-sifat \\
\hline 5 & $\begin{array}{l}\text { Mengaplikasikan konsep } \\
\text { pada pemecahan masalah } \\
\text { dalam proses pembelajaran } \\
\text { matematika }\end{array}$ & $\begin{array}{l}\text { Mengaplikasikan konsep matriks } \\
\text { menyelesaikan masalah }\end{array}$ & \\
\hline
\end{tabular}

\section{HASIL DAN PEMBAHASAN}

Dalam penelitan ini, selama kegiatan belajar mengajar menggunakan model pembelajaran CTL REACT dibentuk kelompok yang terdiri dari 3 kelompok. Dimana tiap-tiap kelompok mengerjakan LKK sebanyak 4 LKK yang terdiri dari 4 sub pokok bahasan yaitu konsep matriks pada pertemuan 1, operasi aljabar pada matriks pada pertemuan 2 , determinan dan invers matriks pada pertemuan 3 , dan penyelesain persamaan linear dua variabel pada pertemuan 4. Adapun hasil yang diperoleh adalah level tiap kelompok untuk tiap-tiap indikator yang telah dibuat oleh peneliti.

Hasil LKK pada pertemuan 1 - 4, tingkat pemahaman konsep matematika siswa yang mencapai level 2 atau lebih setelah penggunaan model pembelajaran CTL REACT pada materi konsep matriks, operasi aljabar pada matriks, determinan dan invers matriks serta penyelesaian sistem persamaan linear dua variabel seperti pada Tabel 2 berikut:

380 BRILIANT: Jurnal Riset dan Konseptual Volume 6 Nomor 2, Mei 2021 
Tabel 2. Tingkat Pemahaman Konsep Matematika Berdasarkan LKK

Pada Pertemuan 1-4

Level Pemahaman Berdasarkan Kelompok

\begin{tabular}{|c|c|c|c|c|c|c|c|c|c|c|c|c|c|}
\hline \multirow{3}{*}{ No. } & \multirow{3}{*}{$\begin{array}{c}\text { Indikator } \\
\text { Pemahaman } \\
\text { Konsep }\end{array}$} & \multicolumn{12}{|c|}{ Level Pemahaman Berdasarkan Kelompok } \\
\hline & & \multicolumn{3}{|c|}{$\begin{array}{c}\text { Konsep } \\
\text { Matriks } \\
\text { (Pertemuan 1) }\end{array}$} & \multicolumn{3}{|c|}{$\begin{array}{c}\text { Operasi } \\
\text { Aljabar pada } \\
\text { Matriks } \\
\text { (Pertemuan 2) }\end{array}$} & \multicolumn{3}{|c|}{$\begin{array}{c}\text { Determinan } \\
\text { dan Invers } \\
\text { Matriks } \\
\text { (Pertemuan 3) }\end{array}$} & \multicolumn{3}{|c|}{$\begin{array}{c}\text { Penyelesaian } \\
\text { Sistem } \\
\text { Persamaan } \\
\text { Linear Dua } \\
\text { Variabel } \\
\text { (Pertemuan 4) }\end{array}$} \\
\hline & & $\mathbf{I}$ & II & III & I & II & III & I & II & III & I & II & III \\
\hline 1 & $\begin{array}{l}\text { Menyatakan ulang } \\
\text { konsep }\end{array}$ & 3 & 3 & 3 & 2 & 2 & 3 & 3 & 2 & 3 & 2 & 3 & 3 \\
\hline 2 & $\begin{array}{l}\text { Mengklasifikasika } \\
\mathrm{n} \text { objek menurut } \\
\text { sifat tertentu }\end{array}$ & 3 & 2 & 3 & 2 & 2 & 2 & 2 & 2 & 2 & 2 & 3 & 2 \\
\hline 3 & $\begin{array}{l}\text { Memberikan } \\
\text { contoh dan bukan } \\
\text { contoh konsep }\end{array}$ & 2 & 2 & 2 & 3 & 3 & 2 & 3 & 3 & 3 & 2 & 3 & 2 \\
\hline 4 & $\begin{array}{l}\text { Menyajikan } \\
\text { konsep dalam } \\
\text { representasi } \\
\text { matematis }\end{array}$ & 3 & 3 & 3 & 3 & 3 & 3 & 3 & 3 & 3 & 2 & 3 & 3 \\
\hline 5 & $\begin{array}{l}\text { Mengaplikasi kan } \\
\text { konsep pada } \\
\text { pemecahan } \\
\text { masalah dalam } \\
\text { proses } \\
\text { pembelajaran } \\
\text { matematika }\end{array}$ & 2 & 3 & 2 & 3 & 3 & 3 & 3 & 3 & 2 & 2 & 3 & 3 \\
\hline
\end{tabular}

Adapun contoh soal dan hasil pekerjaan aktivitas kerja kelompok yang menunjukkan pemahaman konsep siswa pada indikator menyatakan ulang konsep dapat dilihat pada Gambar 2 dan Gambar 3 berikut.

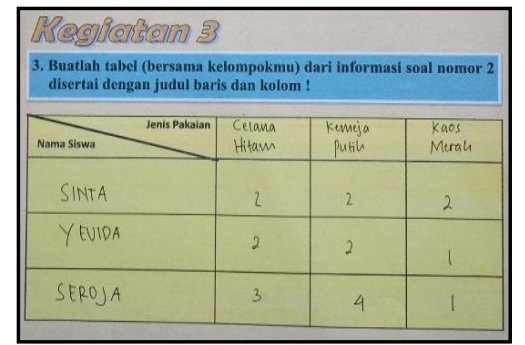


Gambar 2. Aktivitas Kerja Kelompok

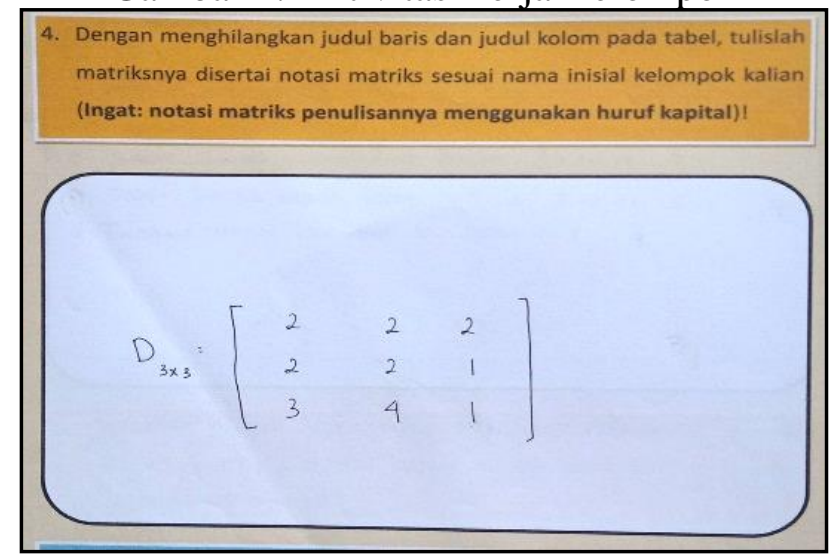

Gambar 3. Jawaban Siswa tentang Indikator Menyatakan Ulang Konsep

Sedangkan contoh hasil pekerjaan aktivitas kerja kelompok yang menunjukkan pemahaman konsep siswa pada indikator menyajikan konsep dalam representasi matematis dapat dilihat pada Gambar 4 dan Gambar 5 berikut.

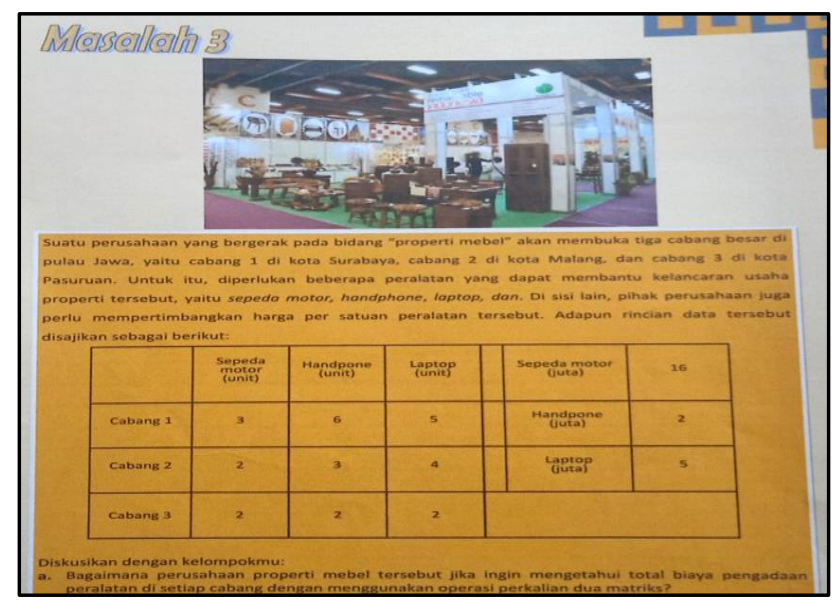

Gambar 4. Aktivitas Kerja Kelompok

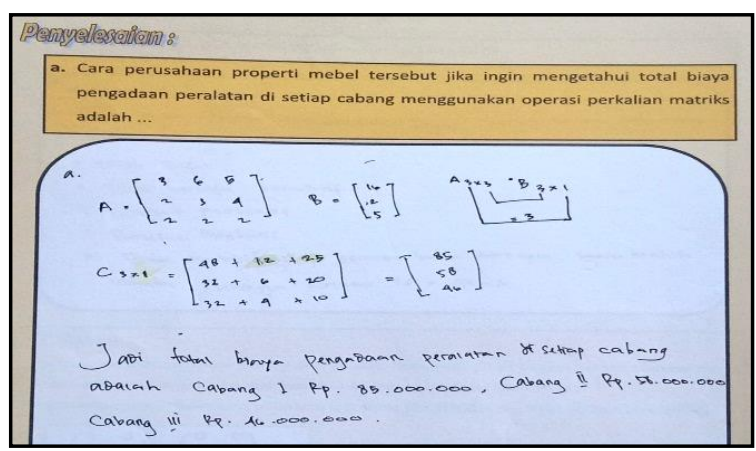

Gambar 5. Jawaban Siswa tentang Indikator Menyajikan Konsep dalam Representasi Matematis

382 BRILIANT: Jurnal Riset dan Konseptual

Volume 6 Nomor 2, Mei 2021 
Indikator kemampuan pemahaman konsep merupakan dasar untuk menilai kemampuan pemahaman konsep siswa (Mawaddah \& Maryanti, 2016). Karena kelompok I terdiri dari 3 siswa, kelompok II dan III masing-masing terdiri dari 4 siswa maka dapat disimpulkan bahwa persentase pemahaman konsep siswa pada pertemuan 1 dalam menyatakan ulang konsep 100\% siswa mencapai level 3. Mengklasifikasikan objek menurut sifat tertentu 63,63\% siswa mencapai level 3 dan 36,36 \% siswa mencapai level 2. Memberikan contoh dan bukan contoh konsep $100 \%$ siswa mencapai level 2. Menyajikan konsep dalam representasi matematis 100\% siswa mencapai level 3 dan mengaplikasikan konsep pada pemecahan masalah dalam proses pembelajaran matematika 63,63\% siswa mencapai level 2 dan 36,36\% siswa mencapai level 3 .

Kriteria dan level pemahaman konsep siswa telah ditetapkan pada setiap indikator yang digunakan dalam penelitian (Khansa, dkk., 2018). Pada pertemuan 2 dapat disimpulkan bahwa persentase pemahaman konsep siswa dalam menyatakan ulang konsep 63,63\% siswa mencapai level 3 dan 36,36\% siswa mencapai level 2. Mengklasifikasikan objek menurut sifat tertentu $100 \%$ siswa mencapai level 2. Memberikan contoh dan bukan contoh konsep 63,63\% siswa mencapai level 3 dan 36,36\% siswa mencapai level 2. Menyajikan konsep dalam representasi matematis $100 \%$ siswa mencapai level 3 dan dalam mengaplikasikan konsep pada pemecahan masalah dalam proses pembelajaran matematika $100 \%$ siswa juga mencapai level 3.

Selanjutnya pada pertemuan 3 dapat disimpulkan bahwa persentase pemahaman konsep siswa dalam menyatakan ulang konsep 63,63\% siswa mencapai level 3 dan 36,36\% siswa mencapai level 2. Mengklasifikasikan objek menurut sifat tertentu $100 \%$ siswa mencapai level 2. Memberikan contoh dan bukan contoh konsep $100 \%$ siswa mencapai level 3. Menyajikan konsep dalam representasi matematis $100 \%$ siswa mencapai level 3 dan dalam mengaplikasikan konsep pada pemecahan masalah dalam proses pembelajaran matematika 63,63\% siswa mencapai level 3 dan 36,36\% siswa mencapai level 2. Hasil persentase pemahaman konsep siswa ini membuktikan bahwa siswa akan mudah memperoleh dan memahami suatu konsep jika melalui suatu pengalaman nyata (Utami, dkk., 2017).

Sedangkan pada pertemuan 4 dapat disimpulkan bahwa persentase pemahaman konsep siswa dalam menyatakan ulang konsep $72,72 \%$ siswa mencapai level 3 dan 27,27\% siswa mencapai level 2. Mengklasifikasikan objek menurut sifat tertentu 63,63\% siswa mencapai level 3 dan 36,36\% siswa mencapai level 2. Memberikan contoh dan bukan contoh konsep 63,63\% siswa mencapai level 3 dan $36,36 \%$ siswa mencapai level 2. Menyajikan konsep dalam representasi matematis $72,72 \%$ siswa mencapai level 3 dan $27,27 \%$ siswa mencapai level 2 dan dalam mengaplikasikan konsep pada pemecahan masalah dalam proses pembelajaran matematika 72,72\% siswa mencapai level 3 dan 27,27\% siswa mencapai level 2.

Perolehan level yang dicapai siswa berkisar di level 2 dan 3 ini menyatakan jika siswa paham dengan konsep matematika (Khansa, dkk., 2018). Ini artinya, siswa paham konsep matematika tentang materi matriks meskipun ada beberapa yang tidak lengkap atau kurang tepat. Siswa memperoleh level 2 jika kelompok paham konsep matematika tetapi tidak lengkap/kurang tepat. Sedangkan siswa 
memperoleh level 3, jika kelompok paham konsep matematika dengan benar dan tepat.

Setelah diperoleh hasil persentase pemahaman konsep siswa dan level pencapaian setiap indikator pada setiap pertemuan, maka dapat disimpulkan bahwa dalam menyatakan ulang konsep 75\% siswa mencapai level 3 dan 25\% siswa mencapai level 2. Mengklasifikasikan objek menurut sifat tertentu 32\% siswa mencapai level 3 dan 68\% siswa mencapai level 2. Memberikan contoh dan bukan contoh konsep 57\% siswa mencapai level 3 dan 43\% siswa mencapai level 2. Menyajikan konsep dalam representasi matematis 93\% siswa mencapai level 3 dan 7\% siswa mencapai level 2 dan dalam mengaplikasikan konsep pada pemecahan masalah dalam proses pembelajaran matematika 68\% siswa mencapai level 3 dan $32 \%$ siswa mencapai level 2. Hal ini sependapat dengan penelitian Khansa, dkk. (2018) bahwa setidaknya $70 \%$ siswa mencapai level 2 atau lebih pada setiap indikator pemahaman konsep matematika.

Pemahaman konsep siswa adalah pemahaman siswa yang berupa penguasaan terhadap suatu konsep, dimana siswa mampu mengungkapkannya kembali dalam bentuk lain yang mudah dimengerti dan mampu mengaplikasikan konsep yang sesuai dengan tingkat perkembangan kognitif yang telah dimilik (Ardianto \& Kuswandi, 2017). Apabila siswa melakukan kegiatan menemukan konsep secara langsung atau terlibat di dalam menemukan suatu konsep, maka siswa akan mudah memahami konsep tersebut (Utami, dkk., 2017). Selanjutnya siswa akan lebih mudah memahami konsep yang lebih kompleks jika siswa tersebut sudah memahami konsep awal dengan baik.

Menurut Setianingsih, dkk. (2017), partisipasi aktif siswa dalam diskusi kelompok kecil dan diskusi kelas secara keseluruhan dapat berfungsi untuk mendorong refleksi siswa tentang strategi yang berbeda dan untuk memfasilitasi siswa berbagi solusi dengan seluruh kelas. Tetapi perlu diingat, rendahnya kualitas interaksi yang terjadi pada proses diskusi juga berdampak pada ketidakmampuan siswa untuk berpartisipasi aktif di kelas (Dewi, dkk., 2019). Sehingga peran guru sangat menentukan proses berlangsungnya diskusi kelompok.

Menurut Hima, dkk. (2019), kegiatan kerja kelompok mampu meningkat motivasi siswa dalam belajar matematika. Kegiatan kerja kelompok selain dapat memperoleh hasil belajar yang lebih baik juga dapat membangkitkan motivasi setiap individu untuk ikut berpartisipasi dan ikut serta dalam mengemukakan pendapat (Agus, 2020). Pada Gambar 2 siswa diminta untuk melakukan aktivitas kerja kelompok yaitu membuat suatu tabel yang diperoleh dari hasil wawancara teman satu kelompok di soal sebelumnya. Kemudian di Gambar 3 siswa mampu menjawab pertanyaan soal nomor 4 dengan benar. Itu membuktikan jika indikator menyatakan ulang konsep tentang matriks sudah tercapai dengan menggunakan aktivitas kerja kelompok.

Pada Gambar 4 siswa diminta untuk melakukan aktivitas kerja kelompok yaitu berdiskusi dengan kelompoknya masing-masing. Kemudian di Gambar 5 siswa mampu menjawab pertanyaan soal point a dengan benar. Itu membuktikan jika indikator menyajikan konsep dalam representasi matematis juga sudah tercapai dengan baik pada aktivitas kerja kelompok yang telah dilakukan. Hal ini sesuai dengan pendapat Lin (2018), bahwa pengetahuan siswa mengalami peningkatan

384 BRILIANT: Jurnal Riset dan Konseptual Volume 6 Nomor 2, Mei 2021 
yang signifikan dengan kerja kelompok dibandingkan dengan bekerja secara individu.

Salah satu langkah dalam pembelajaran kontekstual yaitu adanya pelaksanaan kinerja kelompok (Tatagno, dkk., 2017). Kemudian Pembelajaran matematika yang dilaksanakan secara CTL REACT dalam penelitian ini memberi dampak yang baik dalam hal perkembangan pengetahuan siswa. Sehingga model pembelajaran berbasis CTL REACT dapat dijadikan referensi dalam proses pembelajaran di kelas. Selanjutnya menurut pendapat Ardina, dkk. (2016), Lembar Kerja Siswa (LKS) harus dibuat menarik agar siswa mendapat pengalaman belajar yang menyenangkan. Untuk itu Lembar Kerja kelompok (LKK) berbasis CTL $R E A C T$ yang digunakan dalam penelitian ini perlu adanya perbaikan lagi untuk penelitian lebih lanjut.

\section{KESIMPULAN}

Berdasarkan kegiatan pembelajaran dan hasil penelitian diperoleh bahwa dalam menyatakan ulang konsep 75\% siswa mencapai level 3 dan $25 \%$ siswa mencapai level 2. Mengklasifikasikan objek menurut sifat tertentu 32\% siswa mencapai level 3 dan 68\% siswa mencapai level 2. Memberikan contoh dan bukan contoh konsep 57\% siswa mencapai level 3 dan 43\% siswa mencapai level 2. Menyajikan konsep dalam representasi matematis 93\% siswa mencapai level 3 dan 7\% siswa mencapai level 2 dan dalam mengaplikasikan konsep pada pemecahan masalah dalam proses pembelajaran matematika $68 \%$ siswa mencapai level 3 dan $32 \%$ siswa mencapai level 2. Sehingga dapat disimpulkan bahwa pemahaman konsep siswa berada pada level 2 dan 3. Ini artinya, siswa paham konsep matematika tentang materi matriks meskipun ada beberapa yang tidak lengkap atau kurang tepat.

\section{SARAN}

Penelitian ini bisa digunakan untuk pengembangan penelitian selanjutnya, yaitu diharapkan ada penelitian lanjutan pada sekolah dan materi yang berbeda. Dan beberapa saran yang dapat dijadikan bahan rujukan dalam perbaikan selanjutnya adalah selain menggunakan model pembelajaran CTL REACT, guru perlu menggunakan strategi produktif untuk memfasilitasi proses pembelajaran yaitu dengan metode diskusi kelas sebagai salah satu metode pembelajaran matematika. Sedangkan untuk meningkatkan kreativitas dan kerjasama siswa, guru juga dapat menerapakan strategi outdoor learning yang divariasi dengan outbound agar siswa memahami konsep matematika dan aktif dalam kegitan pembelajaran. Pemahaman konsep siswa juga harus diperhatikan agar tujuan pembelajaran tercapai. Karena dalam mempelajari matematika ada keterkaitan antara konsep satu dengan konsep yang lain.

\section{DAFTAR RUJUKAN}

Aledya, V. (2019). Kemampuan Pemahaman Konsep Matematika pada Siswa. May, 0-7.

Aminullah. (2018). Analisis Kesulitan Mahasiswa Dalam Menyelesaikan Soal Matriks. Logaritma: Jurnal Ilmu-Ilmu Pendidikan Dan Sains, 6(01), 64. 
https://doi.org/10.24952/logaritma.v6i01.1245

Ardianto, W., \& Kuswandi, D. (2017). Pembelajaran Saintifik Berbantuan Media Manipulatif Untuk Memahamkan Konsep Penjumlahan Dan Pengurangan Bilangan Bulat. Jurnal Pendidikan - Teori, Penelitian, Dan Pengembangan, 2(5), 694-705.

Ardina, F. R., Matematika, P., \& Malang, P. N. (2016). Analisis Lembar Kerja Siswa Dalam. 2015, 171-180.

Bingolbali, E., Akkoç, H., Ozmantar, M. F., \& Demri, S. (2011). Pre-service and in-service teachers' views of the sources of students' mathematical difficulties. International Electronic Journal of Mathematics Education, 6(1), 40-59.

Cord. (1999). Teaching Mathematics Contextually. The Cornerstone of Tech Prep, 64. http://www.cord.org/uploadedfiles/Teaching_Math_Contextually.pdf

Dewanti, S. S., Kartowagiran, B., Jailani, J., \& Retnawati, H. (2020). Lecturers' Experience in Assessing 21St-Century Mathematics Competency in Indonesia. Problems of Education in the 21st Century, 78(4), 500-515. https://doi.org/10.33225/pec/20.78.500

Dewi, S. V., Sa'dijah, C., Muksar, M., \& Qohar, A. (2019). The interaction of students in mathematical problem solving with group discussion activities. International Journal of Innovation, Creativity and Change, 10(2), 85-96.

Eggen, P., \& Kauchak, D. (2012). Strategi dan model pembelajaran: Mengajarkan konten dan keterampilan berpikir. Jakarta, Indonesia: Indeks.

Fitriyana, N., \& Purwasi, L. A. (2020). PENGEMBANGAN LEMBAR KERJA SISWA BERBASIS DISCOVERY LEARNING. Jurnal Pendidikan Matematika: Judika Education, $3(1)$. https://doi.org/https://doi.org/10.31539/judika.v3i1.1242

Garegae, K. . (2007). A quest for understanding understanding in mathematics learning: Examining theories of learning. The Mathematics Education into the (Vol. 21)

Hamdani. (2011). Strategi Belajar Mengajar. Bandung: CV Pustaka Setia.

Hima, L. R., Nusantara, T., Hidayanto, E., \& Rahardjo, S. (2019). Changing in mathematical identity of elementary school students through group learning activities. International Electronic Journal of Elementary Education, 11(5), 461-469. https://doi.org/10.26822/iejee.2019553342

Karadeniz, M.H., Kaya, T.B., \& Bozkus, S. (2017). Explanations of prospective middle school mathematics teachers for potential misconceptions on the concept of symmetry. International Electronic Journal of Elementary Education, 10(1), 71-82.

Khansa, S. L., Pramudya, I., \& Kuswardi, Y. (2018). Penerapan Model Pembelajaran Discovery Learning Dengan Strategi Arias Untuk Meningkatkan Pemahaman Konsep Dan Motivasi Belajar Pada Materi Relasi Dan Fungsi. Jurnal Pendidikan Matematika Dan Matematika, 11(4), 259-272.

Lin, S. (2018). The Effect of Group Work on English Vocabulary Learning. 7(4), 163-178. https://doi.org/10.5539/jel.v7n4p163

Mawaddah, S., \& Maryanti, R. (2016). Kemampuan Pemahaman Konsep Matematis Siswa SMP dalam Pembelajaran Menggunakan Model Penemuan Terbimbing (Discovery Learning). EDU-MAT: Jurnal Pendidikan Matematika, 4(1), 76-85. https://doi.org/10.20527/edumat.v4i1.2292

386 BRILIANT: Jurnal Riset dan Konseptual Volume 6 Nomor 2, Mei 2021 
Mawaddah, S., \& Maryanti, R. (2016). Kemampuan Pemahaman Konsep Matematis Siswa SMP dalam Pembelajaran Menggunakan Model Penemuan Terbimbing (Discovery Learning). EDU-MAT: Jurnal Pendidikan Matematika, 4(1), 76-85. https://doi.org/10.20527/edumat.v4i1.2292

Muhammad Agus, P. (2020). HUBUNGAN AKTIVITAS KERJA KELOMPOK DENGAN PRESTASI SISWA KELAS VIII DALAM MATA PELAJARAN PENDIDIKAN AGAMA ISLAM SEKOLAH MENENGAH PERTAMA ISLAM TERPADU AL-WASHLIYAH 20 MEDAN TAHUN AJARAN 2019/2020. 10(2). http://journal.um-surabaya.ac.id/index.php/JKM/article/view/2203

Mulyono, B., \& Hapizah, H. (2018). Pemahaman Konsep Dalam Pembelajaran Matematika. KALAMATIKA Jurnal Pendidikan Matematika, 3(2), 103-122. https://doi.org/10.22236/kalamatika.vol3no2.2018pp103-122

National Council Of Teachers Of Mathematics. (2000). Principles and Standards for School Mathematics. School Science and Mathematics, 47(8), 868-279. https://doi.org/10.1111/j.1949-8594.2001.tb17957.x

Nawas, A. (2018). CONTEXTUAL TEACHING AND LEARNING (CTL) APPROACH THROUGH REACT STRATEGIES ON IMPROVING THE STUDENTS' CRITICAL THINKING IN WRITING. International Journal of Management and Applied Science, 4(7), 46-49. http://creativecommons.org/licenses/by/3.0/

Pangemanan, A. (2020). Application of Contextual Teaching and Learning Approach on Statistics Material Against Student Results. International Education Studies, 13(4), 1. https://doi.org/10.5539/ies.v13n4p1

Prastowo, A. (2012). Panduan Kreatif Membuat Bahan Ajar Inovatif. Yogyakarta: Diva Press.

Purwasi, L. A., \& Fitriyana, N. (2019). Pengembangan Lembar Kerja Siswa Berbasis Pendekatan Open-Ended Untuk Melatih Kemampuan Pemecahan Masalah Matematis Siswa SMP. Kreano, Jurnal Matematika Kreatif-Inovatif, 10(1), 18-26.

Puspita, A. M. I., \& Purwo, S. (2019). Pengaruh Bahan Ajar Berbasis Literasi Dengan Pendekatan Kontekstual Terhadap Hasil Belajar Siswa Sekolah Dasar. Al-Aulad: Journal of Islamic Primary Education, 2(1), 2. https://doi.org/10.15575/al-aulad.v2i1.4426

Rikmasari, R. F. S. H. (2018). Peningkatan Pemahaman Konsep dan Keaktifan Siswa dengan Menggunakan Metode Concept Mapping (Peta Konsep) Kelas IV SDN Kranji II Bekasi Barat. Indonesian Journal of Primary Education, 2(1), 124-129.

Sari, D. P., \& Darhim. (2020). Implementation of react strategy to develop mathematical representation, reasoning, and disposition ability. Journal on Mathematics Education, 11(1), 145-156. https://doi.org/10.22342/jme.11.1.7806.145-156

Setianingsih, R., Sa'dijah, C., As'ari, A. R., \& Muksar, M. (2017). Investigating Fifth- Grade Students ' Construction of Mathematical Knowledge through Classroom Discussion. International Electronic Journal of Mathematics Education, 12(4), 383-396.

Suraji, Maimunah, S. S. (2018). Analisis Kemampuan Pemahaman Konsep 
Matematis dan Kemampuan Pemecahan Masalah Matematis Siswa SMP pada Materi Sistem Persamaan Linear Dua Variabel (SPLDV). Suska Journal of Mathematics Education, 4(4), 9-16. https://doi.org/10.24014/sjme.v3i2.3897

Susiswo. (2014). Folding Back Mahasiswa Dalam Menyelesaikan Masalah Limit

Berdasarkan Pengetahuan Konseptual Dan Pengetahuan Prosedural. Prosiding Seminar Nasional TEQIP (Teachers Quality Improvement Program) Dengan Tema "Membangun Karakter Bangsa Melalui Pembelajaran Bermakna TEQIP” Pada 1 Desember 2014 Di Universitas Negeri Malang.

Tatagno, A. Y. P., Sa'dijah, C., \& Akbar, S. (2017). Penerapan Asesmen Autentik dalam Pembelajaran Konstektual pada Materi Pecahan. Jurnal Pendidikan: Teori, Penelitian, Dan Pengembangan, 2(6), 736-742.

Utami, F. D., Djatmika, E. T., \& Sa'dijah, C. (2017). Pengaruh Model Pembelajaran terhadap Pemahaman Konsep, Sikap Ilmiah, dan Kemampuan Pemecahan Masalah Matematis Ditinjau dari Motivasi Belajar Siswa Kelas IV. Jurnal Pendidikan: Teori, Penelitian Dan Pengembangan, 2(12), 1629-1638.

Zahara, E., Murni, A., \& Hutapea, N. (2020). Development of Mathematics Learning Tools by Implementing Numbered Head Together Type Cooperative Models to Improve Students' Mathematical Understanding Ability in Matrix Topic. Journal of Educational Sciences, 4(4), 190-204. 